Article

\title{
Study of Ni/Al-Fe Catalyst Stability in the Aqueous Phase Hydrogenolysis of Glycerol
}

\author{
Raquel Raso, Lucia García *(D), Joaquín Ruiz, Miriam Oliva and Jesús Arauzo \\ Thermochemical Processes Group (GPT), Aragon Institute of Engineering Research (I3A), \\ Universidad de Zaragoza, Mariano Esquillor S/N, 50018 Zaragoza, Spain; rroka@unizar.es (R.R.); \\ jruizp@unizar.es (J.R.); miroliva@unizar.es (M.O.); jarauzo@unizar.es (J.A.) \\ * Correspondence: luciag@unizar.es
}

Received: 25 November 2020; Accepted: 17 December 2020; Published: 18 December 2020

\begin{abstract}
The present work studied the stability and reusability of Ni/Al-Fe catalyst in the aqueous phase hydrogenolysis of glycerol without external hydrogen addition. The catalyst based on 28 molar \% of $\mathrm{Ni}$ with $3 / 1$ molar ratio of $\mathrm{Al} / \mathrm{Fe}$ was prepared through co-precipitation. This catalyst presented the best performance in our last study which compares several Ni/Al-Fe catalysts with different molar ratios of $\mathrm{Al} / \mathrm{Fe}$. To see the influence of the pressurized water on the physicochemical characteristics of $\mathrm{Ni} / \mathrm{Al}-\mathrm{Fe}$ catalyst, a test of up to $9 \mathrm{~h}$ has been carried out. Fresh and used catalysts were characterized by various techniques: $\mathrm{X}$-ray Diffraction (XRD), $\mathrm{N}_{2}$-physisorption, field emission scanning electron microscopy (FESEM) and STEM. Glycerol conversion and carbon yield to gases and liquids did not vary significantly when compared at $3 \mathrm{~h}$ and $9 \mathrm{~h}$. Furthermore, the morphology of the catalyst remains stable after continuous recycling under severe hydrothermal conditions. The nickel rich phase of the catalyst, which was determined by XRD and scanning transmission electron microscopy (STEM) techniques, showed a stable size after $9 \mathrm{~h}$ under reaction.
\end{abstract}

Keywords: glycerol; in situ hydrogen; fixed bed; stability

\section{Introduction}

Nowadays, the production of biodiesel has been given considerable attention due to the growing concerns regarding environmental contamination and the depletion of existing fossil fuel reserves. Biodiesel is mainly produced by transesterification, where several triglycerides (vegetable oils, animal fats or waste oils, among others) react with an alcohol such as methanol or ethanol in the presence of a catalyst. From the biodiesel production, glycerol is obtained as a subproduct; about 0.1 ton is generated for every 1 ton of biodiesel. The surplus glycerol negatively affects the economics of the biodiesel industry [1-3]. Therefore, the conversion of glycerol into value-added products, such as $\mathrm{H}_{2}$ and 1,2-propanediol, among others, is a method to improve the economics of biodiesel as it has been the case during the last decade. Many works have been published on aqueous phase hydrogenolysis (APH) of glycerol using different catalysts such as: noble metals ( $\mathrm{Pt}, \mathrm{Ru}, \mathrm{Pd}$ or $\mathrm{Rh}$ ), transition metals $(\mathrm{Ni}, \mathrm{Cu}$ or $\mathrm{Zr}$ ) and bi-metallics (Ni-Cu or Pt-Fe) supported on activated carbon, several oxides, or mixed oxides [4-18].

In recent years, Ni-based catalysts have attracted considerable attention due to their low price and high activity $[19,20]$. However, the major disadvantage of Ni-based catalysts is the low stability because of coke deposition and Ni sintering which cause catalyst deactivation and block the catalytic active sites and catalyst pores $[15,19]$. Hence, work continues on the development of multi-functional catalysts with coking inhibition, anti-sintering, significant activity, and stability [19]. Bastan et al. [21] found that mixed-oxide catalysts $\left(\mathrm{Ni} / \mathrm{Al}_{\mathrm{x}} \mathrm{Mg}_{\mathrm{y}}\right)$ and the $\mathrm{Ni} / \mathrm{Mg}$ catalyst were relatively more stable for $25 \mathrm{~h}$ of reaction time than the $\mathrm{Ni} / \mathrm{Al}$ catalyst. Moreover, the mixed-oxide catalysts demonstrated best glycerol 
conversion and selectivity towards $\mathrm{H}_{2}$ production in comparison to the $\mathrm{Ni} / \mathrm{Al}$ and $\mathrm{Ni} / \mathrm{Mg}$ catalysts in the following order: $\mathrm{Ni} / \mathrm{Al}_{2} \mathrm{Mg}_{1}>\mathrm{Ni} / \mathrm{Al}_{1} \mathrm{Mg}_{1}>\mathrm{Ni} / \mathrm{Al}_{1} \mathrm{Mg}_{2}>\mathrm{Ni} / \mathrm{Al}>\mathrm{Ni} / \mathrm{Mg}$. Therefore, the results revealed that the mixed oxide supports had a good stability and activity in converting biomass into hydrogen through aqueous phase reforming of glycerol [21]. In addition, Fan et al. [22] found that Mg-Al oxide supported $\mathrm{Ni}$ catalyst $\left(\mathrm{Ni} / \mathrm{Mg}_{2} \mathrm{Al}(\mathrm{O})\right)$, indicated higher activity at low reaction temperature and had a much better thermal stability (for $8 \mathrm{~h}$ of reaction duration at $700{ }^{\circ} \mathrm{C}$ ) than the $\mathrm{Ni} / \mathrm{MgO}$ and Ni/ $\mathrm{Al}_{2} \mathrm{O}_{3}$ catalysts, respectively, for synthetic natural gas from syngas. In our previous study [18], we showed that mixed-oxide catalysts $\left(\mathrm{Ni} / \mathrm{Al}_{\mathrm{x}} \mathrm{Fe}_{\mathrm{y}}\right.$ ) showed a better catalyst performance than the $\mathrm{Ni} / \mathrm{Al}$ and $\mathrm{Ni} / \mathrm{Fe}$ catalysts, with the $\mathrm{Ni} / \mathrm{Al}_{3} \mathrm{Fe}_{1}$ catalyst being the best for hydrogenolysis of glycerol. Consequently, this work studied the stability and reusability of $\mathrm{Ni} / \mathrm{Al}-\mathrm{Fe}$ catalyst, in particular the $\mathrm{Ni} / \mathrm{Al}_{3} \mathrm{Fe}_{1}$ catalyst. In addition, the effect of pressurized water on the physicochemical characteristics of the catalyst was examined. Fresh and used catalysts were characterized by different techniques such as X-ray diffraction (XRD), $\mathrm{N}_{2}$-physisorption, FESEM, and scanning transmission electron microscopy (STEM).

\section{Results and Discussion}

\subsection{Catalyst Stability and Reusability Study}

In this work, the stability and reusability of $\mathrm{Ni} / \mathrm{Al}_{3} \mathrm{Fe}_{1}$ catalyst for aqueous phase hydrogenolysis of glycerol without hydrogen addition was studied at $227^{\circ} \mathrm{C}$ and 34 absolute bars, with $10 \%$ glycerol in deionized water as feed for $1 \mathrm{~h}$ and upon 3 successive runs of duration of $3 \mathrm{~h}$ each $(9 \mathrm{~h}$ of total reaction time). Figure 1 shows the glycerol conversion and carbon yield to gases and liquids. The carbon yield to gas or liquids is calculated as the percentage of the carbon fed into glycerol that is converted to gas or liquids. In Section 3.2, this is explained in depth. Clearly $\mathrm{Ni} / \mathrm{Al}_{3} \mathrm{Fe}_{1}$ catalyst maintained catalytic activity over successive runs. Carbon yield to gases and liquids and glycerol conversion did not vary significantly when compared at $3 \mathrm{~h}$ and $9 \mathrm{~h}$. Thus, the behavior of the catalyst was quite stable during a period of $9 \mathrm{~h}$. In addition, this catalyst shows more selectivity for liquid products than for gas products. The values of the glycerol conversion and carbon yield to liquids and gases are between $41 \%-52 \%$, $23 \%-29 \%$ and $5 \%-10 \%$, respectively. Carbon yield to liquids at $1,3,6$ and $9 \mathrm{~h}$ is in experimental error because of the overlapping of error bars. Glycerol conversion and carbon yield to gases at $6 \mathrm{~h}$ show a slightly high value.

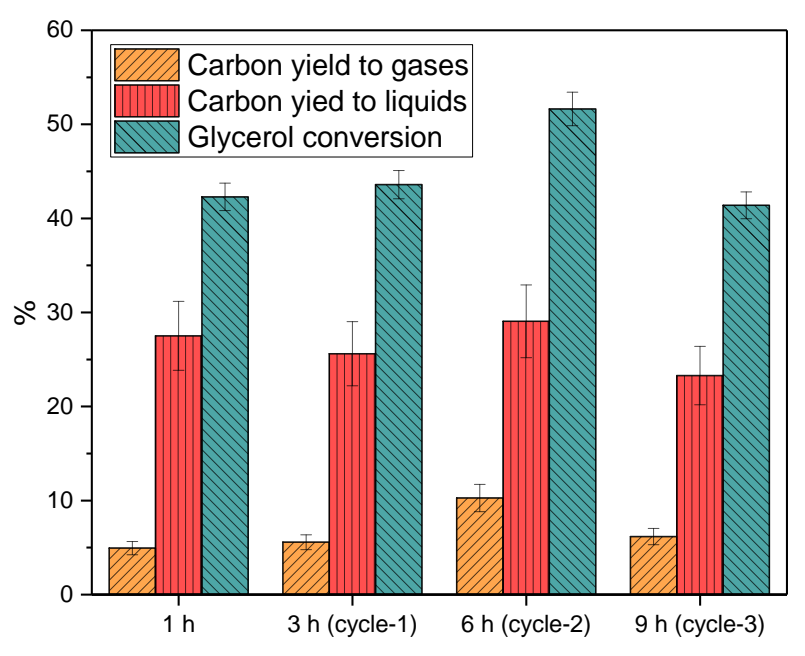

Figure 1. Glycerol conversion and carbon yield to gases and liquids.

Consequently, Figure 2 shows the carbon selectivity to liquids for the different experiments. It is observed that the main liquid products are 1,2-propanediol, acetol, ethylene glycol and ethanol, 1,2-propanediol having the highest value at between $61-71 \%$. A low amount of methanol and acetic acid is obtained. There was a slight decrease in the amount of acetol with increasing reaction time. 
Meanwhile the amount of ethylene glycol increased. In addition, a slight increase in the amount of ethanol and methanol was observed with increasing reaction time, while the 1,2-propanediol and acetic acid practically remained constant. It is well known that there are two main routes to obtain the liquid products during the APH of glycerol (Scheme 1). Route 1 is the formation of acetol by the dehydration of glycerol and 1,2-propanediol production by subsequent hydrogenation of acetol. This is the main route in hydrogenolysis of glycerol. Route 2 is the production of glyceraldehyde by the dehydrogenation of glycerol and then its consequent de-carbonylation to form ethylene glycol. Then, ethanol and methanol can be generated by dehydration/hydrogenation and dehydrogenation/de-carbonylation of ethylene glycol, respectively. Ethanol can also produce acetic acid [7,23]. According to the results obtained, it is possible that route 2 was favoured with an increase of reaction time and could occur after $6 \mathrm{~h}$ of reaction, corroborated with the results of glycerol conversion and carbon yield to gases and liquids.

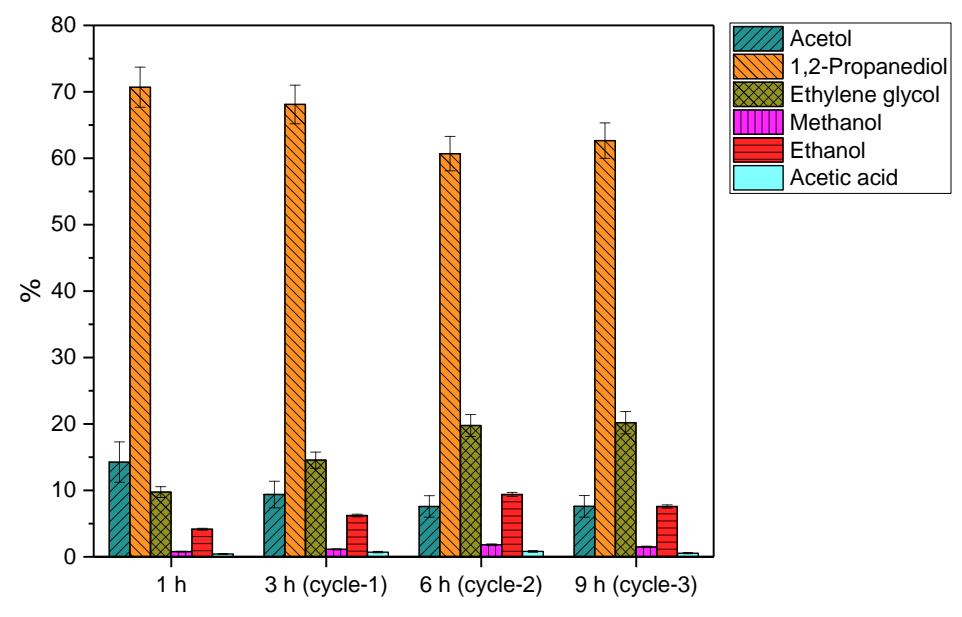

Figure 2. Carbon selectivity to liquids.

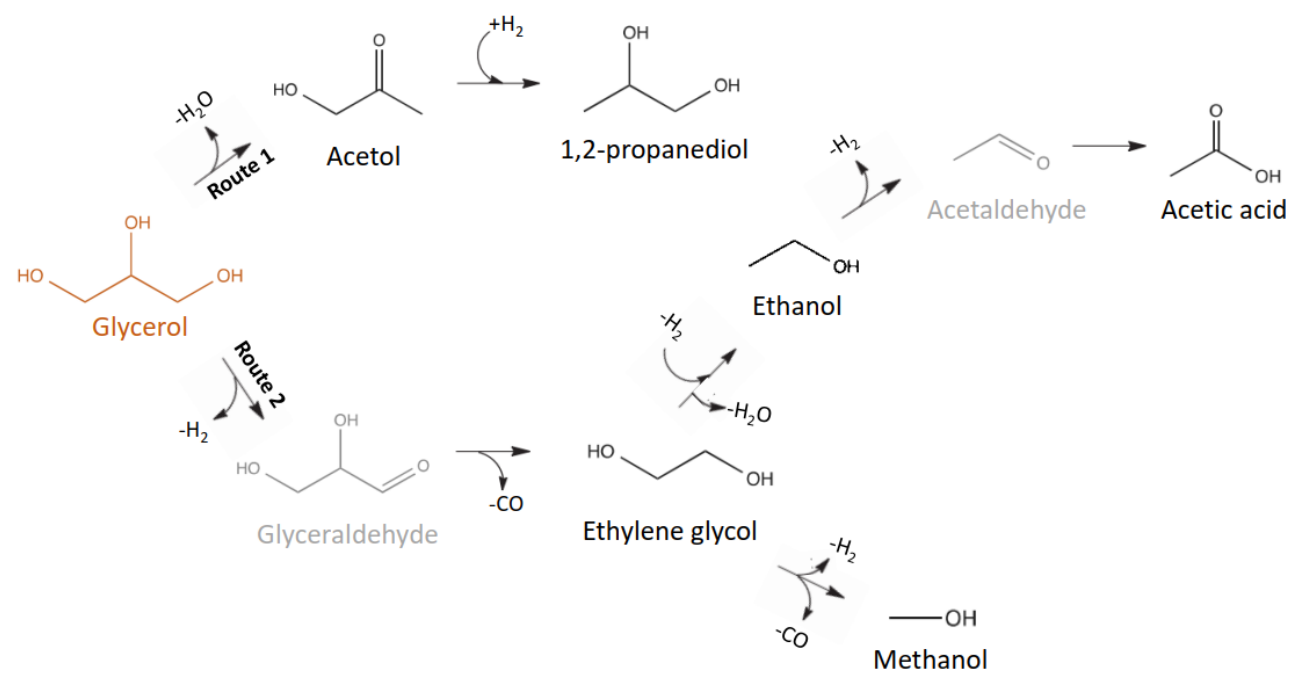

Scheme 1. The two main routes to obtain the liquid products during the aqueous phase hydrogenolysis (APH) of glycerol.

In addition, the liquid products were submitted to ICP-OES analysis to determine if metal had been leached after the APH reaction of glycerol takes place. Trace amounts of $\mathrm{Ni}, \mathrm{Al}$ and Fe were detected in the liquid product (Figure 3). The \% presented on Figure 3 represents the accumulated amount of leached metal. This is the percentage for each metal of total leached amount with respect to the initial amount in the catalyst. It is observed that $\mathrm{Al}$ in very low amounts is the only metal leached when $\mathrm{H}_{2} \mathrm{O}$ is fed into the reactor. Fe is the metal that leached the most and then Ni. The explanation for this could be that the leaching took place during the APH reaction because of the acid nature of the reaction 
medium. Collected liquid products had a $\mathrm{pH}$ of around 4 as reported by Morales-Marín et al. [20]. This $\mathrm{pH}$ can be a consequence of the dissolved $\mathrm{CO}_{2}$ and/or the presence of soluble oxygenated compounds generated in the APH reaction of glycerol [20,24]. Arandia et al. [25] reported a significant metal leaching when the feedstock included acetic acid. Under these conditions, no effect on the deactivation catalyst is observed with the amount of metal leaching. Additionally, it could be that Fe delayed the deactivation of the Ni-based catalyst [26] because of the unvarying results of the catalyst performance. The leaching of $4 \% \mathrm{Fe}$ after $9 \mathrm{~h}$ of run could indicate that the Fe is present in excess in the catalyst.

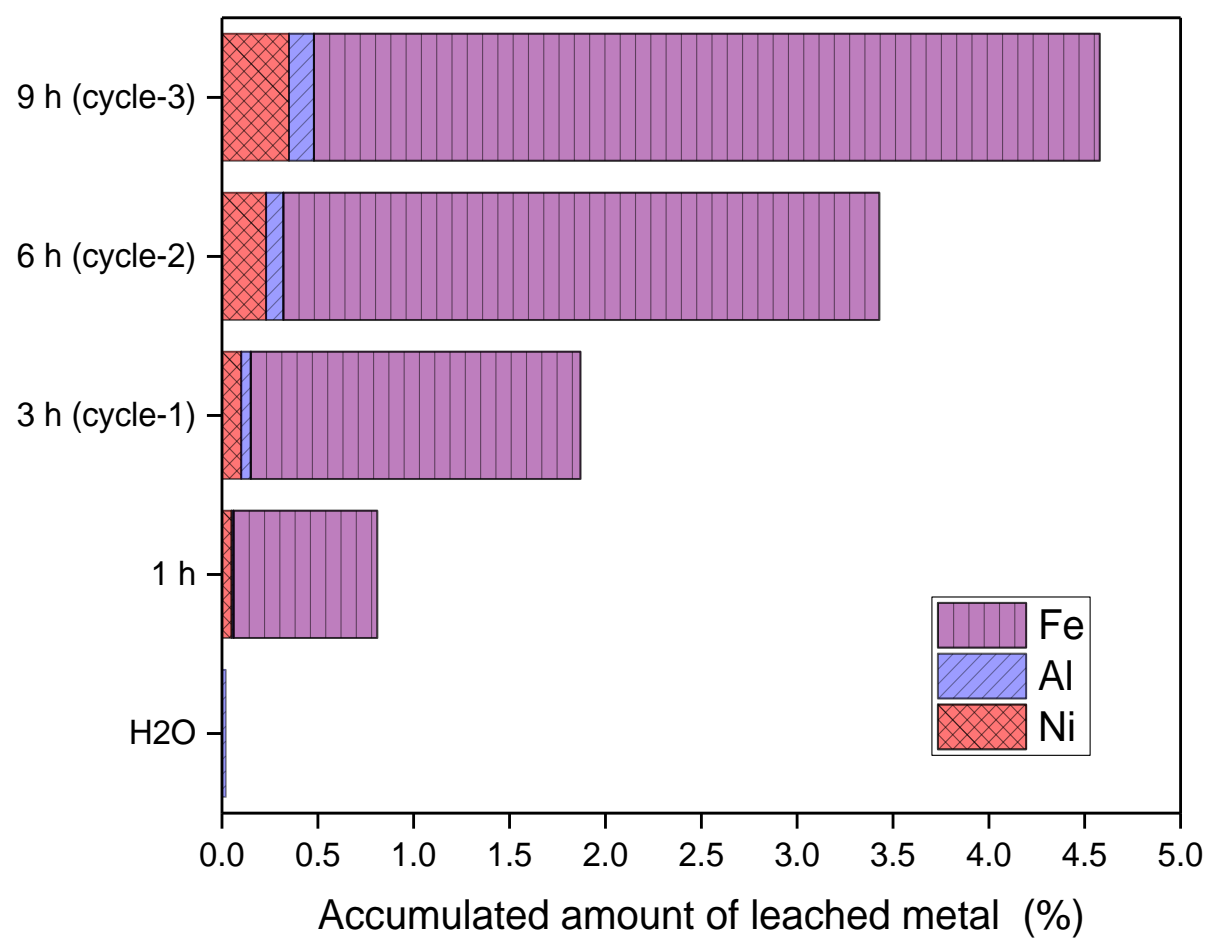

Figure 3. Metal leached after APH of glycerol takes place.

It is well known that metal leaching, metal particles sintering, the adsorption of organic species, carbon formation, etc., are considered the reasons for the catalyst deactivation $[6,27,28]$. Metal particles sintering has been studied by XRD technique and the results are shown in the following section.

Furthermore, elemental analysis of the $1 \mathrm{~h}$ and $9 \mathrm{~h}$ samples was performed to determine the coke formation. It is observed that the $\%$ of $\mathrm{C}$ and $\mathrm{H}$ did not vary between the samples. About $2.6 \mathrm{wt} . \%$ $\mathrm{C}$ and $1.7 \mathrm{wt} . \% \mathrm{H}$ are obtained. Moreover, it is analyzed that the ratio $\mathrm{mg} \mathrm{C} / \mathrm{g}_{\text {catalyst }} \mathrm{g}_{\text {glycerol reacted }}$ decreased with an increase in reaction time from 10.79 to 1.13 for $1 \mathrm{~h}$ and $9 \mathrm{~h}$, respectively. That means that coke formation does not increase after prolonged contact time.

It is observed that glycerol conversion and carbon yield to gases at $6 \mathrm{~h}$ show a slightly high value. Moreover, higher carbon selectivity to ethylene glycol is observed at $6 \mathrm{~h}$ than at lower time-on-stream. These two facts could be explained considering the obtained results: Fe is leached in higher proportion than $\mathrm{Ni}$, the leached $\mathrm{Fe}$ could provide more active centres with $\mathrm{Ni}$ and these centres, rich in $\mathrm{Ni}$, could favour the route 2 . We do not have characterization results to demonstrate this, so it is just a hypothesis. Ni has the capability to break the C-C bond effectively towards ethylene glycol production [13].

\subsection{Catalyst Characterization}

The XRD patterns of fresh and used samples are presented in Figure 4. The NiO (bunsenite, JCPDS 00-001-1239), $\gamma$ - $\mathrm{Al}_{2} \mathrm{O}_{3}$ (JCPDS 00-029-0063), $\mathrm{NiAl}_{2} \mathrm{O}_{4}$ (JCPDS 00-010-0339), $\mathrm{Fe}_{2} \mathrm{O}_{3}$ (JCPDS 00-001-1053), $\mathrm{Fe}_{3} \mathrm{O}_{4}$ (JCPDS 00-001-1111) and $\mathrm{FeAl}_{2} \mathrm{O}_{4}$ (JCPDS 01-086-2320) phases are observed in the calcined sample. Contrariwise, there are not differences between the XRD patterns of the reduced sample with 
the used samples except for the presence of the boehmite phase (JCPDS 01-074-1895) in the spent samples. In addition, the $\mathrm{NiO}$ and $\mathrm{Fe}_{2} \mathrm{O}_{3}$ phases were missing after the reduction of the catalyst and the $\mathrm{FeNi}_{3}$ (JCPDS 03-065-3244) and $\mathrm{AlNi}_{3}$ (JCPDS 00-050-1265) phases appeared.

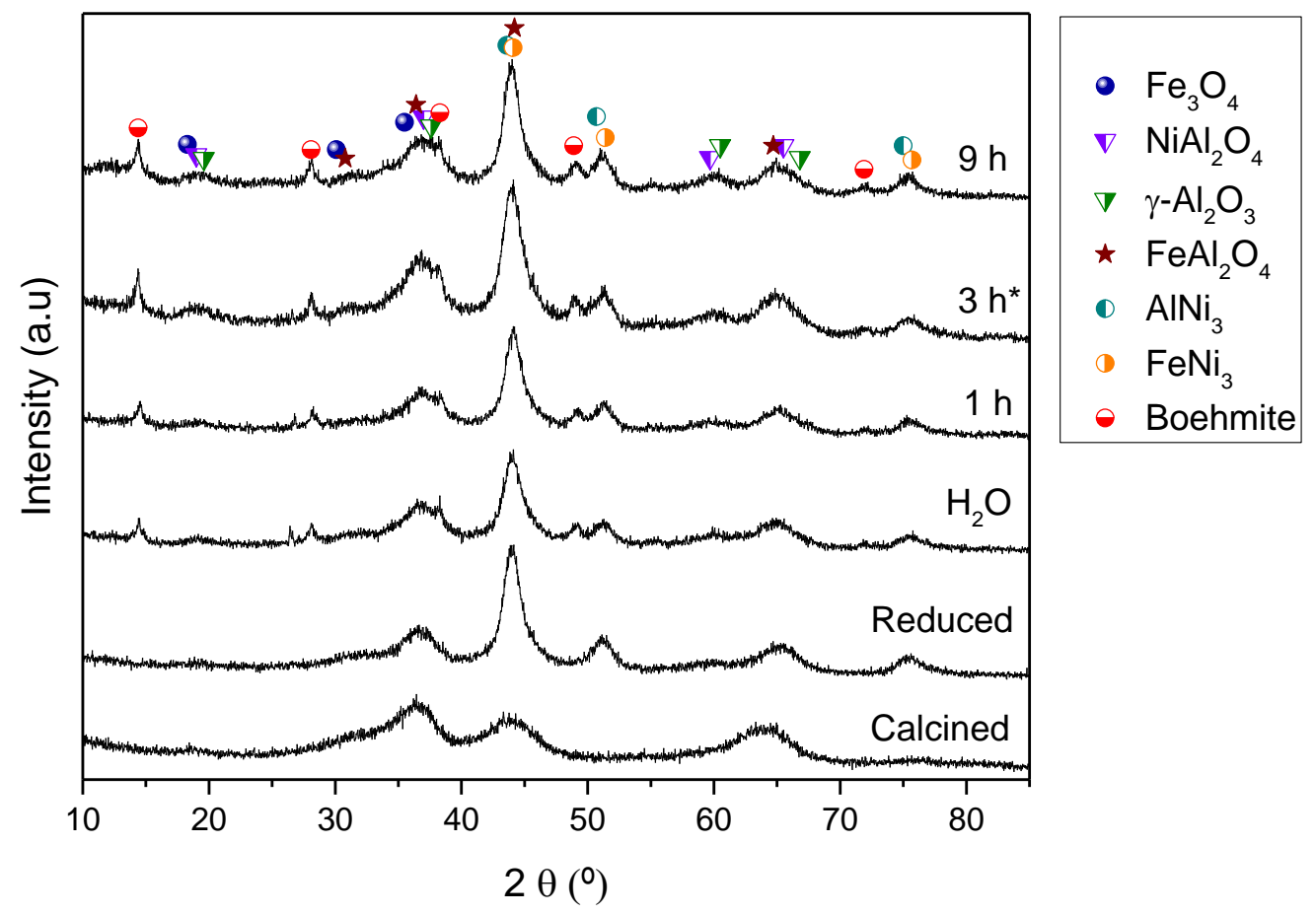

Figure 4. X-ray Diffraction (XRD) patterns of fresh and used samples. * Raso et al. [18].

The formation of the $\mathrm{FeNi}_{3}$ phase after the activation step by catalyst reduction has shown a relevant role in the conversion of glycerol into 1,2-propanediol [18]. All samples present approximately the same $\mathrm{FeNi}_{3}$ crystallite size from the reduced to $9 \mathrm{~h}$ sample (Table 1). This means the Ni/ $\mathrm{Al}_{3} \mathrm{Fe}_{1}$ catalyst is stable, in concordance with the results of catalyst performance.

Table 1. Textural properties, $\mathrm{FeNi}_{3}$ crystallite size and scanning transmission electron microscopy (STEM) results of the samples. Boehmite crystallite size.

\begin{tabular}{|c|c|c|c|c|c|c|}
\hline Sample & $\begin{array}{l}S_{\text {BET }} 1 \\
\left(\mathrm{~m}^{2} / \mathrm{g}\right)\end{array}$ & $\begin{array}{c}\mathrm{V}_{\mathrm{p}}{ }^{2} \\
\left(\mathrm{~cm}^{3} / \mathrm{g}\right)\end{array}$ & $\underset{(\mathrm{nm})}{\mathrm{d}_{\mathrm{p}}{ }^{2}}$ & $\begin{array}{c}\mathrm{FeNi}_{3}{ }^{3} \\
(\mathrm{~nm})\end{array}$ & $\begin{array}{c}\text { STEM }^{4} \\
(\mathrm{~nm})\end{array}$ & $\begin{array}{c}\text { Boehmite } \\
(\mathrm{nm})\end{array}$ \\
\hline Calcined $^{6}$ & 222 & 0.211 & 3.93 & - & - & - \\
\hline Reduced & 168 & 0.262 & 6.25 & 5 & 8.2 & - \\
\hline $\mathrm{H}_{2} \mathrm{O}$ & 207 & 0.192 & 5.40 & 5 & 8.4 & 14 \\
\hline $1 \mathrm{~h}$ & 210 & 0.189 & 4.75 & 6 & 8.5 & 11 \\
\hline $3 h^{6}$ & 215 & 0.151 & 3.94 & 5 & 8.4 & 15 \\
\hline $9 \mathrm{~h}$ & 210 & 0.153 & 4.18 & 6 & 8.2 & 17 \\
\hline
\end{tabular}

${ }^{1}$ The Brunauer, Emmett and Teller (BET) method. ${ }^{2} \mathrm{BJH}$ adsorption method. ${ }^{3} \mathrm{FeNi}_{3}$ crystallite size calculated from Scherrer equation. ${ }^{4}$ Mean particle size of nickel-rich phase. ${ }^{5}$ Boehmite crystallite size calculated from Scherrer equation. ${ }^{6}$ Raso et al. [18].

The boehmite is observed before the APH reaction takes place (Figure 4: $\mathrm{H}_{2} \mathrm{O}$ sample). This means that the water used to stabilize the system (at temperature and pressure of APH of glycerol) is the main factor for the boehmite formation. It is obtained by the reaction of $\mathrm{Al}_{2} \mathrm{O}_{3}$ with $\mathrm{H}_{2} \mathrm{O}$. In addition, the boehmite crystallite size was between 11 to $17 \mathrm{~nm}$ (Table 1).

Despite leached metal, a high level of performance is obtained after $9 \mathrm{~h}$ of reaction time that could be due to excess of Fe in the catalyst as was cited above. A detailed analysis of Figure 4 does not 
show significant differences in the XRD patterns for the used catalyst for 1, 3 and $9 \mathrm{~h}$. Because the samples present low crystallinity, it is not possible to propose which is the crystalline phase of the $\mathrm{Fe}$ that is leached. Perhaps, the leached Fe could be present in an amorphous phase not detected by XRD. The obtained results could indicate that the leached Fe does not show a catalytic effect in the reaction.

Figure 5 shows the $\mathrm{N}_{2}$ adsorption-desorption isotherms of fresh and used samples. According to the International Union of Pure and Applied Chemistry (IUPAC) classification [29], these isotherms correspond to the type IV, characteristic of mesoporous materials with a hysteresis loop that occurred after $p / p_{o}=0.4$. The samples present a hysteresis of type $\mathrm{H}_{2}$ which is typical of mesoporous materials with interconnected pores of different shape and size [29].
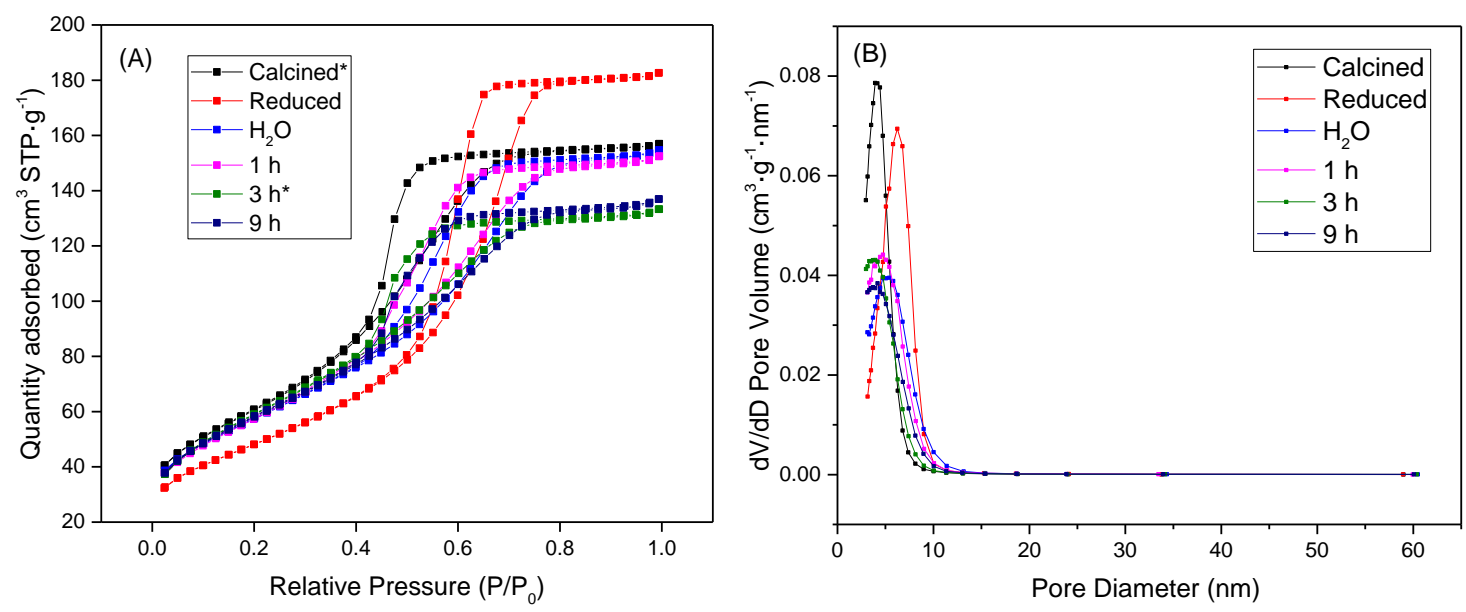

Figure 5. (A) $\mathrm{N}_{2}$ adsorption-desorption isotherms and (B) Barrett-Joyner-Halenda (BJH) adsorption pore size distribution of fresh and used samples. ${ }^{*}$ Raso et al. [18].

Table 1 shows the textural properties of fresh and used samples. The Brunauer, Emmett and Teller (BET) and Barrett-Joyner-Halenda(BJH) methods have been employed. It is observed that after reduction, the pore diameter increased by around $59 \%$ and the specific area declined up to $24 \%$, caused by the migration of the metallic $\mathrm{Ni}$ from the $\mathrm{NiAl}_{2} \mathrm{O}_{4}$ lattice to the surface. Then, the specific area of spent samples increased and there are almost no differences between them $\left(\mathrm{H}_{2} \mathrm{O}, 1 \mathrm{~h}, 3 \mathrm{~h}\right.$ and $\left.9 \mathrm{~h}\right)$. This behavior could be due to the boehmite leaching from the catalyst surface. It is well known that $\gamma$-alumina could be hydrated to a boehmite or gibbsite phase under hydrothermal conditions, because hydroxides are thermodynamically more stable than $\gamma$-alumina [24]. The increased surface area could benefit the stability of the catalyst [30]. Conversely, the pore diameter and volume decrease with the reaction time until $3 \mathrm{~h}$ and at this moment they remain approximately constant.

Figure 6 shows the STEM images and metal particle size distribution of the reduced and used samples. The nickel-rich particle size of the samples is measured by image processing software. Around one hundred particles were measured per sample. It was observed that the mean diameter values for the reduced and used samples $\left(\mathrm{H}_{2} \mathrm{O}, 1 \mathrm{~h}, 9 \mathrm{~h}\right)$ were around $8 \mathrm{~nm}$, as reported by Raso et al. [18] for this type of catalyst used during $3 \mathrm{~h}$ of reaction. This means that the $\mathrm{Ni} / \mathrm{Al}_{3} \mathrm{Fe}_{1}$ catalyst is stable during $9 \mathrm{~h}$ of aqueous phase hydrogenolysis of glycerol, as was observed during the catalyst test and corroborated with the XRD technique. 

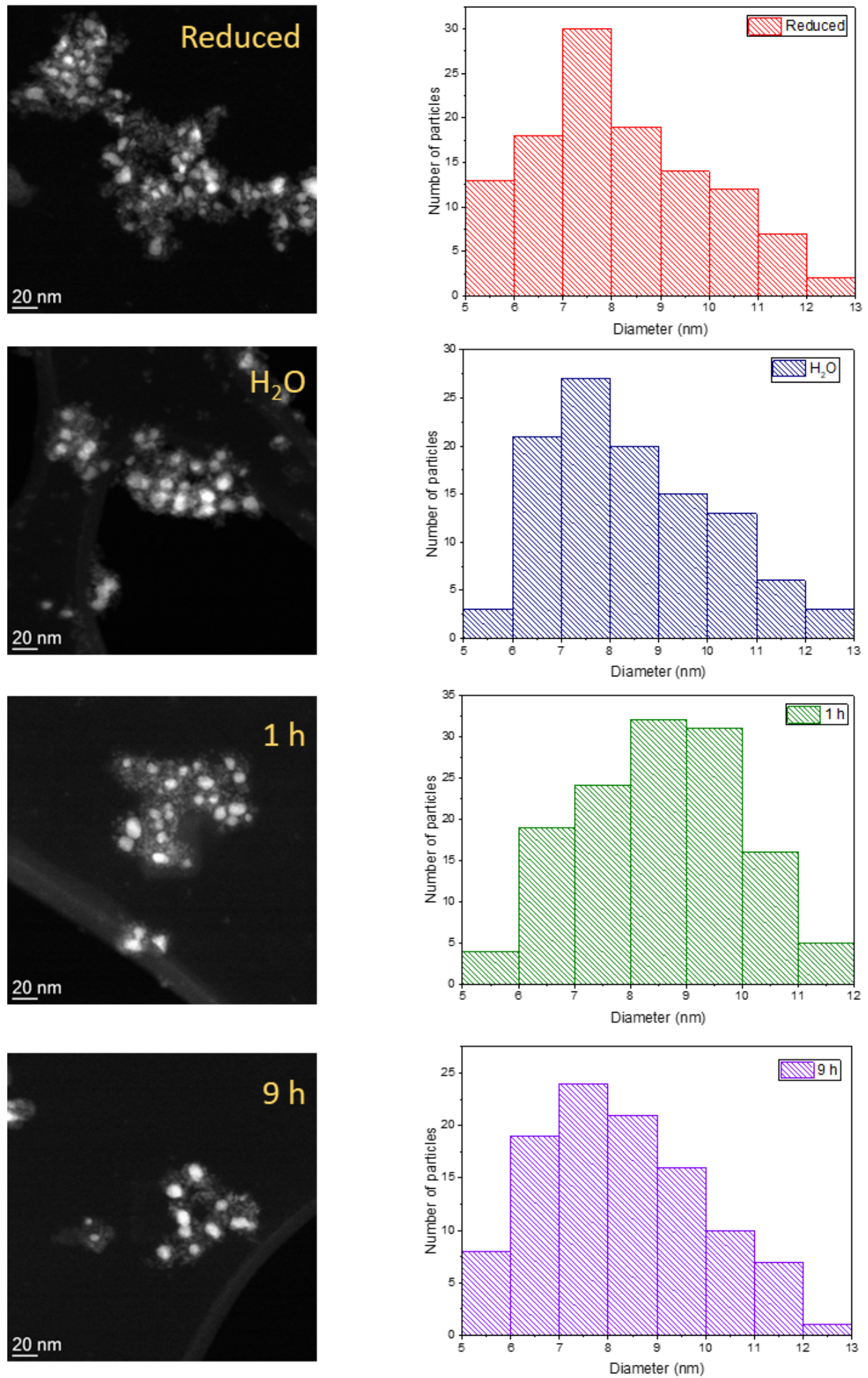

Figure 6. STEM images and metal particle size distribution of the reduced and used samples $\left(\mathrm{H}_{2} \mathrm{O}, 1 \mathrm{~h}\right.$ and $9 \mathrm{~h}$. 
Figure 7 shows the field emission scanning electron microscopy (FESEM) images of the reduced and used samples. It is observed that the morphology of $\mathrm{Ni} / \mathrm{Al}_{3} \mathrm{Fe}_{1}$ catalyst changes after its use. There is almost no difference between the used samples with differences in treatment from just feeding water into the reactor until $9 \mathrm{~h}$ of reaction. The $\mathrm{Ni} / \mathrm{Al}_{3} \mathrm{Fe}_{1}$ catalyst presented considerable morphology stability despite the hydrothermal conditions that occur during the reaction [18].
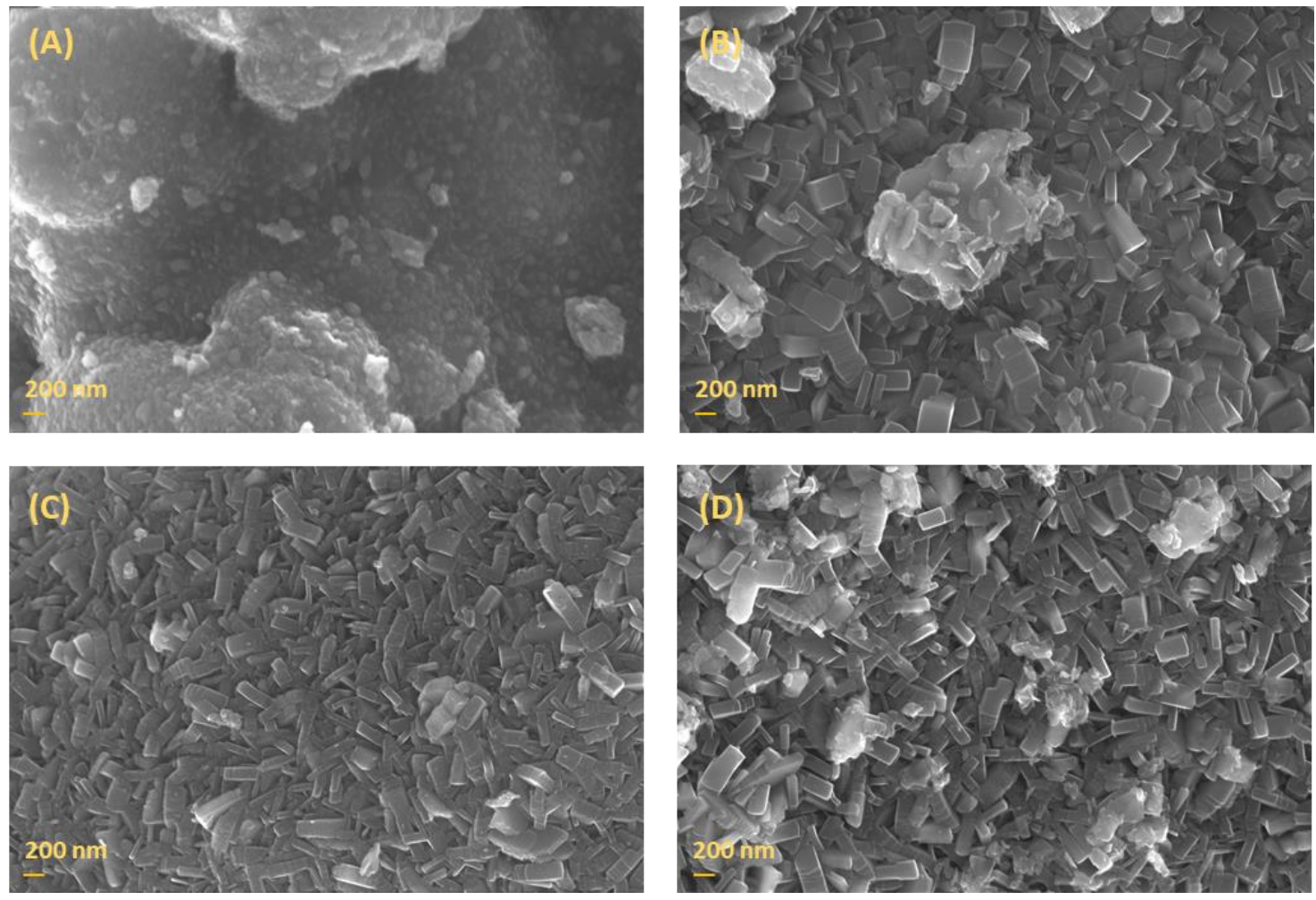

Figure 7. FESEM images of the reduced (A) and used samples: $\mathrm{H}_{2} \mathrm{O}(\mathbf{B}), 1 \mathrm{~h}(\mathbf{C})$ and $9 \mathrm{~h}(\mathbf{D})$.

Single atom alloy catalysts were employed by Zhang et al. [31] in 1,2-propanediol production by glycerol hydrogenolysis. The PtCu single atom alloy catalyst showed excellent catalytic performance. Single atom alloy catalysts are a promising area to be investigated due to the beneficial effect of metal dispersion and the synergistic effect when combining two active metals [32]. This is a relevant field that should be explored for Ni/Al-Fe catalysts in order to develop more active, selective and stable catalysts for 1,2-propanediol by glycerol hydrogenolysis.

\section{Materials and Methods}

\subsection{Catalyst Preparation and Characterization}

The Ni/Al-Fe catalyst with 28 molar \% of $\mathrm{Ni}$ and 3/1 of molar ratio of $\mathrm{Al} / \mathrm{Fe}$ was prepared by the co-precipitation method as reported earlier and the catalyst was named $\mathrm{Ni} / \mathrm{Al}_{3} \mathrm{Fe}_{1}$ [18]. It was calcined at $500{ }^{\circ} \mathrm{C}$ during $3 \mathrm{~h}$. The catalyst was sieved to a mesh size of $160-315 \mu \mathrm{m}$. It was characterized by various methods such as $\mathrm{N}_{2}$-physisorption, $\mathrm{X}$-ray diffraction (XRD), field emission scanning electron microscopy (FESEM), scanning transmission electron microscopy (STEM), after calcination, reduction, feeding $\mathrm{H}_{2} \mathrm{O}$ and different time of reaction ( 1 and $9 \mathrm{~h}$ ). Detailed catalyst characterization procedure is described in our previous communication [18].

\subsection{Catalyst Tests}

The study of the $\mathrm{Ni} / \mathrm{Al}_{3} \mathrm{Fe}_{1}$ catalyst stability was carried out in a continuous pressurized fixed bed reactor at $1 \mathrm{~h}$ of reaction and upon 3 successive runs at $227^{\circ} \mathrm{C}$ and 34 absolute bar. The experimental 
system was developed and designed by PID (Process Integral Development Eng. \& Tech, Madrid, Spain). It consists mainly of a stainless-steel tubular reactor (inner diameter of $9 \mathrm{~mm}$ ) heated up by means an electric furnace and a micrometric valve, which regulates the pressure system. The fixed bed is constituted of a mixture of catalyst $(2 \mathrm{~g})$ and inert sand $(5 \mathrm{~g})$ with the same mesh size $(160-315 \mu \mathrm{m})$ and is put inside the tubular reactor between quartz wool supports. The feeding was an aqueous solution of $10 \mathrm{wt} . \%$ glycerol (purity: $\geq 99.5 \%$, Sigma-Aldrich, St. Louis, MO, USA) in deionized water during the reaction of aqueous phase hydrogenolysis of glycerol, that was fed into the reactor by using a high-performance liquid chromatography (HPLC) pump (Gilson 307 HPLC Piston Pump, Champaign, IL, USA). The total flow was $1 \mathrm{~mL} / \mathrm{min}$ with the mass of catalyst/glycerol mass flow rate ratio $(\mathrm{W} / \mathrm{m})$ of $20 \mathrm{~g}_{\text {catalyst }} \cdot \mathrm{min} / \mathrm{g}_{\text {glycerol }}$.

Prior to the start the experiments, the calcined catalyst was reduced in situ at $500{ }^{\circ} \mathrm{C}$ during $1 \mathrm{~h}$ using a $\mathrm{H}_{2}$ stream of $100 \mathrm{~cm}^{3}$ (STP)/min. The reduction temperature was stablished from the catalyst characterization results by $\mathrm{H}_{2}$-TPR [18]. Then, before starting the reaction, deionized water with a flow rate of $1 \mathrm{~mL} / \mathrm{min}$ was fed to stabilize temperature and pressure to reaction conditions for about $2 \mathrm{~h}$. Hence, in this work the influence of the water on the physicochemical characteristics of $\mathrm{Ni} / \mathrm{Al}_{3} \mathrm{Fe}_{1}$ catalyst was studied.

The reaction products (gas and liquid) exiting from the reactor is depressurised by means of the micrometric valve and arrives at the condensation system. The condensation system consists of four condensers and the first one was employed to collect the water used to stabilize the system. The other condensers were used to gather the liquid products. The exit gas mixture $\left(\mathrm{N}_{2}, \mathrm{H}_{2}, \mathrm{CH}_{4}, \mathrm{CO}_{2}, \mathrm{CO}\right.$, $\mathrm{C}_{2} \mathrm{H}_{6}$ and $\mathrm{C}_{3} \mathrm{H}_{8}$ ) was analysed online by means of an Agilent 490 Micro-GC equipped with Thermal Conductivity Detectors (TCD) (Santa Clara, CA, USA). The liquid products (methanol (MeOH), ethanol (EtOH), acetol, acetic acid, 1,2-propanediol (1,2-PDO), ethylene glycol (EG) and non-reacted glycerol) were analysed offline with an Agilent 7820A GC equipped with a Flame Ionization Detector (FID) and a HP-FFAP Agilent 19091F-105 capillary column (Santa Clara, CA, USA). In addition, the liquid products were submitted to an inductively coupled plasma optical emission spectrometry (ICP-OES) analysis to study metal leaching, using a Thermo Elemental IRIS Intrepid Radial with an automatic injector (Markham, ONT, Canada). More details of the experimental rig can be found in our previous study [18].

The stability of the catalyst was explored in repeated experiments for $3 \mathrm{~h}$ in order to test its reuse. Reusability of the catalyst was tested using the reaction conditions above but with the previous and only catalyst reduction in the first cycle. 3 total cycles were analyzed for $3 \mathrm{~h}$ ( $9 \mathrm{~h}$ in total).

The catalytic performance was calculated according to expressions (1)-(3) below [18].

The global glycerol conversion was calculated as follows:

$$
\text { Glycerol conversion }(\%)=\frac{\mathrm{n}_{\text {glycerol }}^{\text {in }}-\mathrm{n}_{\text {glycerol }}^{\text {out }}}{n_{\text {glycerol }}^{\text {in }}} \times 100
$$

where $n_{\text {glycerol }}^{\text {in }}$ and $n_{\text {glycerol }}^{\text {out }}$ are the moles of glycerol fed and the moles of unreacted glycerol in the exit liquid, respectively.

The carbon yield to liquids and carbon yield to gases were defined as follows:

$$
\begin{gathered}
\text { Carbon yield to liquids }(\%)=\frac{\mathrm{n}_{\mathrm{MeOH}}+2 \mathrm{n}_{\mathrm{EtOH}}+2 \mathrm{n}_{\text {Acetic acid }}+3 \mathrm{n}_{\text {Acetol }}+3 \mathrm{n}_{1,2-\mathrm{PDO}}+2 \mathrm{n}_{\mathrm{EG}}}{3 \times \mathrm{n}_{\text {glycerol }}^{\text {in }}} \times 100 \\
\text { Carbon yield to gases }(\%)=\frac{\mathrm{n}_{\mathrm{CO}}+\mathrm{n}_{\mathrm{CO}_{2}}+\mathrm{n}_{\mathrm{CH}_{4}}+2 \mathrm{n}_{\mathrm{C}_{2} \mathrm{H}_{6}}+3 \mathrm{n}_{\mathrm{c}_{3} \mathrm{H}_{8}}}{3 \times \mathrm{n}_{\text {glycerol }}^{\text {in }}} \times 100
\end{gathered}
$$

where $n_{i}$ are the moles of each i product, $\mathrm{i}$ being the liquid or gas products.

The carbon selectivity to liquid products was defined as the percentage ratio of carbon in a liquid product to the total carbon in all the analysed liquid products. Unreacted glycerol was not considered. 
There is not total coincidence between the glycerol conversion and the addition of the carbon yield to products (gas and liquid) due to errors in analysing and collecting the samples. An experiment with a value of carbon deficit below $\mathrm{o} \%$ was considered a reliable test, as reported by other authors $[7,18,23]$. The carbon deficit was defined as follows:

Carbon deficit $=$ Glycerol conversion $-($ carbon yield to gases + carbon yield to liquids $)$

\section{Conclusions}

In this study, $\mathrm{APH}$ of glycerol under $\mathrm{Ni} / \mathrm{Al}_{3} \mathrm{Fe}_{1}$ catalyst was performed during $9 \mathrm{~h}$ and the influence of the pressurized water on the physicochemical characteristics of the catalyst was analyzed. Structural stability and reusability of the $\mathrm{Ni} / \mathrm{Al}_{3} \mathrm{Fe}_{1}$ catalyst were verified under the reaction conditions. All samples present approximately the same $\mathrm{FeNi}_{3}$ crystallite size from the reduced to $9 \mathrm{~h}$ samples. The morphology of the catalyst remains stable after successive reuses under severe hydrothermal conditions. The carbon yield to gases and liquids and glycerol conversion did not change significantly when compared at $3 \mathrm{~h}$ and $9 \mathrm{~h}$. Although trace amounts of $\mathrm{Ni}, \mathrm{Al}$ and Fe were detected in the liquid product, this did not cause deactivation of the catalyst under the operating conditions. In addition, the boehmite was formed by the reaction of $\mathrm{Al}_{2} \mathrm{O}_{3}$ with $\mathrm{H}_{2} \mathrm{O}$ under the operation conditions, prior to the APH of glycerol. Meanwhile, the metals leaching occurred during the APH of glycerol.

Author Contributions: Conceptualization-L.G. and M.O.; Methodology-R.R. and J.R.; Software-R.R.; Validation-R.R.; Formal analysis-R.R. and J.R.; Investigation, R.R.; Writing-original draft preparation-R.R.; Writing-review and editing-R.R., L.G., J.R., M.O. and J.A.; Visualization-R.R.; Supervision-L.G. and J.A.; Project administration-L.G.; Funding acquisition-L.G. and J.A. All authors have read and agreed to the published version of the manuscript.

Funding: This research was funded by AEI/FEDER, UE (project CTQ2017-86893-R) and Aragón Government (ref. T22_20R), co-funded by FEDER 2014-2020 “Construyendo Europa desde Aragón”.

Acknowledgments: The authors like to acknowledge the use of the Servicio General de Apoyo a la Investigación-SAI of the Universidad de Zaragoza.

Conflicts of Interest: The authors declare no conflict of interest. The funders had no role in the design of the study; in the collection, analyses, or interpretation of data; in the writing of the manuscript, or in the decision to publish the results.

\section{References}

1. Mahlia, T.; Syazmi, Z.; Mofijur, M.; Abas, A.; Bilad, M.; Ong, H.; Silitonga, A. Patent landscape review on biodiesel production: Technology updates. Renew. Sustain. Energy Rev. 2020, 118, 109526. [CrossRef]

2. Chozhavendhan, S.; Singh, M.V.P.; Fransila, B.; Kumar, R.P.; Devi, G.K. A review on influencing parameters of biodiesel production and purification processes. Curr. Res. Green Sustain. Chem. 2020,1-2, 1-6. [CrossRef]

3. Zhou, C.; Zhao, H.; Tong, D.; Wu, L.; Yu, W. Recent Advances in Catalytic Conversion of Glycerol. Catal. Rev. Sci. Eng. 2013, 55, 369-453. [CrossRef]

4. Jimenez-Morales, I.; Vila, F.; Mariscal, R.; Jimenez-Lopez, A. Hydrogenolysis of glycerol to obtain 1,2-propanediol on Ce-promoted Ni/SBA-15 catalysts. Appl. Catal. B Environ. 2012, 117, 253-259. [CrossRef]

5. Soares, A.; Atia, H.; Armbruster, U.; Passos, F.; Martin, A. Platinum, palladium and nickel supported on Fe3O4 as catalysts for glycerol aqueous-phase hydrogenolysis and reforming. Appl. Catal. A Gen. 2017, 548, 179-190. [CrossRef]

6. Cai, F.; Pan, D.; Ibrahim, J.; Zhang, J.; Xiao, G. Hydrogenolysis of glycerol over supported bimetallic Ni/Cu catalysts with and without external hydrogen addition in a fixed-bed flow reactor. Appl. Catal. A Gen. 2018, 564, 172-182. [CrossRef]

7. Roy, D.; Subramaniam, B.; Chaudhari, R. Aqueous phase hydrogenolysis of glycerol to 1,2-propanediol without external hydrogen addition. Catal. Today 2010, 156, 31-37. [CrossRef]

8. Dasari, M.; Kiatsimkul, P.; Sutterlin, W.; Suppes, G. Low-pressure hydrogenolysis of glycerol to propylene glycol. Appl. Catal. A Gen. 2005, 281, 225-231. [CrossRef]

9. Freitas, I.; Manfro, R.; Souza, M. Hydrogenolysis of glycerol to propylene glycol in continuous system without hydrogen addition over Cu-Ni catalysts. Appl. Catal. B Environ. 2018, 220,31-41. [CrossRef] 
10. Zhou, W.; Zhao, Y.; Wang, S.; Ma, X. The effect of metal properties on the reaction routes of glycerol hydrogenolysis over platinum and ruthenium catalysts. Catal. Today 2017, 298, 2-8. [CrossRef]

11. Maris, E.; Davis, R. Hydrogenolysis of glycerol over carbon-supported Ru and Pt catalysts. J. Catal. 2007, 249, 328-337. [CrossRef]

12. Shinmi, Y.; Koso, S.; Kubota, T.; Nakagawa, Y.; Tomishige, K. Modification of $\mathrm{Rh} / \mathrm{SiO}_{2}$ catalyst for the hydrogenolysis of glycerol in water. Appl. Catal. B Environ. 2010, 94, 318-326. [CrossRef]

13. Chimentao, R.; Miranda, B.; Ruiz, D.; Gispert-Guirado, F.; Medina, F.; Llorca, J.; Santos, J. Catalytic performance of zinc-supported copper and nickel catalysts in the glycerol hydrogenolysis. J. Energy Chem. 2020, 42, 185-194. [CrossRef]

14. Miranda, B.; Chimentao, R.; Santos, J.; Gispert-Guirado, F.; Llorca, J.; Medina, F.; Bonillo, F.; Sueiras, J. Conversion of glycerol over 10\%Ni/gamma-Al2O3 catalyst. Appl. Catal. B Environ. 2014, 147, 464-480. [CrossRef]

15. Pudi, S.; Biswas, P.; Kumar, S.; Sarkar, B. Selective Hydrogenolysis of Glycerol to 1,2-Propanediol Over Bimetallic Cu-Ni Catalysts Supported on gamma- $\mathrm{Al}_{2} \mathrm{O}_{3}$. J. Braz. Chem. Soc. 2015, 26, 1551-1564. [CrossRef]

16. Soares, A.; Perez, G.; Passos, F. Alumina supported bimetallic Pt-Fe catalysts applied to glycerol hydrogenolysis and aqueous phase reforming. Appl. Catal. B Environ. 2016, 185, 77-87. [CrossRef]

17. Seretis, A.; Tsiakaras, P. Hydrogenolysis of glycerol to propylene glycol by in situ produced hydrogen from aqueous phase reforming of glycerol over $\mathrm{SiO}_{2}-\mathrm{Al}_{2} \mathrm{O}_{3}$ supported nickel catalyst. Fuel Process. Technol. 2016, 142, 135-146. [CrossRef]

18. Raso, R.; García, L.; Ruiz, J.; Oliva, M.; Arauzo, J. Aqueous phase hydrogenolysis of glycerol over Ni/Al-Fe catalysts without external hydrogen addition. Appl. Catal. B Environ. 2021, 283, 119598. [CrossRef]

19. He, Z.; Peng, Y.; Jiao, Y. Improved catalytic stability and anti-coking ability of $\mathrm{Ni} / \mathrm{La}_{2} \mathrm{O}_{3}-\mathrm{Al}_{2} \mathrm{O}_{3}$ catalyst by doping alkaline earth metals for n-decane reforming. Int. J. Hydrog. Energy 2020, 45, 24626-24635. [CrossRef]

20. Morales-Marin, A.; Ayastuy, J.; Iriarte-Velasco, U.; Gutierrez-Ortiz, M.; Environm, C.T. Nickel aluminate spinel-derived catalysts for the aqueous phase reforming of glycerol: Effect of reduction temperature. Appl. Catal. B Environ. 2019, 244, 931-945. [CrossRef]

21. Bastan, F.; Kazemeini, M.; Larimi, A.; Maleki, H. Production of renewable hydrogen through aqueous-phase reforming of glycerol over Ni/Al2O3-MgO nano-catalyst. Int. J. Hydrog. Energy 2018, 43, 614-621. [CrossRef]

22. Fan, M.; Miao, K.; Lin, J.; Zhang, H.; Liao, D. Mg-Al oxide supported Ni catalysts with enhanced stability for efficient synthetic natural gas from syngas. Appl. Surf. Sci. 2014, 307, 682-688. [CrossRef]

23. Garcia, L.; Valiente, A.; Oliva, M.; Ruiz, J.; Arauzo, J. Influence of operating variables on the aqueous-phase reforming of glycerol over a Ni/Al coprecipitated catalyst. Int. J. Hydrog. Energy 2018, 43, 20392-20407. [CrossRef]

24. Reynoso, A.; Ayastuy, J.; Iriarte-Velasco, U.; Gutierrez-Ortiz, M.; Environm, C.T. Cobalt aluminate spinel-derived catalysts for glycerol aqueous phase reforming. Appl. Catal. B Environ. 2018, 239, 86-101. [CrossRef]

25. Arandia, A.; Coronado, I.; Remiro, A.; Gayubo, A.; Reinikainen, M. Aqueous-phase reforming of bio-oil aqueous fraction over nickel-based catalysts. Int. J. Hydrog. Energy 2019, 44, 13157-13168. [CrossRef]

26. Tezel, E.; Figen, H.; Baykara, S. Hydrogen production by methane decomposition using bimetallic Ni-Fe catalysts. Int. J. Hydrog. Energy 2019, 44, 9930-9940. [CrossRef]

27. Callison, J.; Subramanian, N.; Rogers, S.; Chutia, A.; Gianolio, D.; Catlow, C.; Wells, P.; Dimitratos, N. Directed aqueous-phase reforming of glycerol through tailored platinum nanoparticles. Appl. Catal. B Environ. 2018, 238, 618-628. [CrossRef]

28. Oliveira, A.; Baeza, J.; Calvo, L.; Alonso-Morales, N.; Heras, F.; Lemus, J.; Rodriguez, J.; Gilarranz, M. Exploration of the treatment of fish-canning industry effluents by aqueous-phase reforming using $\mathrm{Pt} / \mathrm{C}$ catalysts. Environ. Sci. Water Res. Technol. 2018, 4, 1979-1987. [CrossRef]

29. Thommes, M.; Kaneko, K.; Neimark, A.; Olivier, J.; Rodriguez-Reinoso, F.; Rouquerol, J.; Sing, K. Physisorption of gases, with special reference to the evaluation of surface area and pore size distribution (IUPAC Technical Report). Pure Appl. Chem. 2015, 87, 1051-1069. [CrossRef]

30. Li, J.; Mei, X.; Zhang, L.; Yu, Z.; Liu, Q.; Wei, T.; Wu, W.; Dong, D.; Xu, L.; Hu, X. A comparative study of catalytic behaviors of $\mathrm{Mn}, \mathrm{Fe}, \mathrm{Co}, \mathrm{Ni}, \mathrm{Cu}$ and $\mathrm{Zn}$ e Based catalysts in steam reforming of methanol, acetic acid and acetone. Int. J. Hydrog. Energy 2020, 45, 3815-3832. [CrossRef] 
31. Zhang, X.; Cui, G.; Feng, H.; Chen, L.; Wang, H.; Wang, B.; Zheng, L.; Hong, S.; Wei, M. Platinum-copper single atom alloy catalysts with high performance towards glycerol hydrogenolysis. Nat. Commun. 2019, 10, 5812. [CrossRef] [PubMed]

32. Hannagan, R.; Giannakakis, G.; Flytzani-Stephanopoulos, M.; Sykes, E. Single-Atom Alloy Catalysis. Chem. Rev. 2020, 120, 12044-12088. [CrossRef] [PubMed]

Publisher's Note: MDPI stays neutral with regard to jurisdictional claims in published maps and institutional affiliations.

(C) 2020 by the authors. Licensee MDPI, Basel, Switzerland. This article is an open access article distributed under the terms and conditions of the Creative Commons Attribution (CC BY) license (http://creativecommons.org/licenses/by/4.0/). 